\section{Pecan Shell Mulch Impact on 'Loring' Peach Tree Establishment and First Harvest}

\author{
Eric T. Stafne ${ }^{1,4}$, Charles T. Rohla ${ }^{2}$, and Becky L. Carroll ${ }^{3}$
}

AdDitional InDEX wORDs. weed control, production, Prunus persica, Carya illinoinensis

Summary. Pecan (Carya illinoinensis) shells are waste products that are occasionally used for mulch in ornamental landscape settings, yet most shell waste is left in piles near the shelling facility or discarded by other methods. If another use for this waste product could be developed, it may add income for pecan producers and provide peach (Prunus persica) growers with another option for weed control. A block of 'Loring' peach trees grafted onto 'Halford' rootstocks was planted at a spacing of $18 \times 22 \mathrm{ft}$ in Feb. 2005 at the Cimarron Valley Research Station near Perkins, OK, to determine the effect of pecan shell mulch on peach trees. Five treatments were imposed: no weed control except mowing (MOW), weed-free $6-\times 6$-ft area maintained with glyphosate herbicide $($ SPRAY), 6-ft $\times 6$ - $\mathrm{ft} \times 2$-inch deep mulch (TWO), 6-ft $\times 6$-ft $\times 4$-inch deep mulch (FOUR), and 6-ft $\times 6$-ft $\times 6$-inch deep mulch (SIX). Yields in 2008 were poorest in the MOW treatment $(13.2 \mathrm{~kg} /$ tree and 93 fruit/tree). All other treatments did not differ. Soluble solids concentration as a measure of fruit quality and fruit weight was unaffected by treatment. Tree height, pruning weights, and trunk cross-sectional area were similar with the exception that MOW was lower for all three growth measurements beginning in 2007. Pecan mulch appears to have the potential to reduce soil $\mathrm{pH}$. Foliar analysis for nitrogen $(\mathrm{N})$, potassium (K), and zinc $(\mathrm{Zn})$ showed treatment differences in 2006. No treatment differences were evident in 2007 and 2008 for $\mathrm{K}$ and $\mathrm{Zn}$, but in 2008, FOUR had greater $\mathrm{N}$ than MOW. Tree mortality increased with pecan mulch depth. MOW, SPRAY, and TWO had little tree loss (0\%-5\%), whereas FOUR and SIX had $15 \%$ and $35 \%$ mortality, respectively. Tree mortality was attributed to record rains in 2007 coupled with longer soil moisture retention under the deeper mulch.

$\mathrm{W}$ eed management is a challenge in all fruit crops. Most weeds are controlled with appropriately labeled herbicides; however, sometimes herbicide application is not a viable option due to plant sensitivity, timing issues (i.e., preharvest intervals), or organic certification standards. Some of these weed issues may be mitigated by the appropriate use of mulches. Mulches provide several advantages over a bare-ground orchard floor because they conserve soil moisture [which

Partial funding of this project provided by the Oklahoma Agricultural Experiment Station, by the Oklahoma Pecan Growers' Association, and by the Samuel Roberts Noble Foundation.

Mention of a trademark, proprietary product, or vendor does not constitute a guarantee or warranty of the product by Oklahoma State University and does not imply its approval to the exclusion of other products or vendors that also may be suitable.

${ }^{1}$ Assistant Professor, 358 Agricultural Hall, Department of Horticulture and Landscape Architecture, Oklahoma State University, Stillwater, OK 74078

${ }^{2}$ Horticulturist, The Samuel Roberts Noble Foundation, Ardmore, OK 73401

${ }^{3}$ Senior Agriculturist, 358 Agricultural Hall, Department of Horticulture and Landscape Architecture, Oklahoma State University, Stillwater, OK 74078

${ }^{4}$ Corresponding author. E-mail: eric.t.stafne@okstate. edu. may also lessen cold injury during droughty conditions (Smith, 2000)], insulate the soil against temperature extremes, and prevent soil erosion (Stefanelli et al., 2009). Mulches generally are beneficial to young fruit trees during establishment because of the weed barrier they provide (Baxter, 1970; Foshee et al., 1996, 1999; Lord and Vlach, 1973; Merwin et al., 1995).

Although mulches can be beneficial, there are potential negative ramifications of using mulches. Baxter (1970) found that mulching with 15 $\mathrm{cm}$ of straw applied every 2 years increased growth and production of peach and apple (Malus $\times$ domestica) compared with cultivation or maintaining the orchard in pasture grasses, but the cost involved in maintenance and application of the straw was high, it posed a fire risk, it decomposed rapidly, and it could lead to waterlogging of the soil, potentially resulting in plant death. Overall though, he concluded that using mulch could result in a net overall profit from fruit sales due to increased harvests from mulched trees. Belding et al. (2004) noted that grass mulch applied without pre-emergence herbicides led to vole (Microtus spp.) problems, resulting in a $45 \%$ mortality rate of the peach trees. Plots maintained without mulch and with pre-emergent herbicides provided no cover for voles and resulted in no tree loss. A secondary issue is nutmeat fragments left in pecan shells used for mulch that may support toxigenic fungi. In one study, Penicillium charlesii was found to be harmful to wildlife and plant life in controlled laboratory and greenhouse situations (Cole et al., 1981).

Some mulches are organically derived products and others are manmade. Studies using shell mulches are few. Porter et al. (2005) used macadamia (Macadamia integrifolia) shell mulch on mature macadamia trees and found that the shell mulch led to increased root growth, larger trunks, and in drier conditions, higher nut-inshell yield. Shell mulch could provide farmers with an additional organic orchard management tool. In Oklahoma, pecan shells are a waste product of the established pecan industry that could be used for mulch. Most of the available literature suggests that pecan shells can be an effective mulch (Black et al., 1994; Mexal et al., 2003; Skelly, 2005), but scientific data are lacking.

Mexal et al. (2003) reported that the New Mexico/western Texas pecan

\begin{tabular}{llll}
\hline $\begin{array}{l}\text { Units } \\
\text { To convert U.S. to SI, } \\
\text { multiply by }\end{array}$ & U.S. unit & SI unit & $\begin{array}{l}\text { To convert SI to U.S., } \\
\text { multiply by }\end{array}$ \\
\hline 10 & $\%$ & $\mathrm{mg} \cdot \mathrm{g}^{-1}$ & 0.1 \\
1 & $\mathrm{cbar}$ & $\mathrm{kPa}$ & 1 \\
0.3048 & $\mathrm{ft}$ & $\mathrm{m}$ & 3.2808 \\
2.54 & inch(es) & $\mathrm{cm}$ & 0.3937 \\
25.4 & inch(es) & $\mathrm{mm}$ & 0.0394 \\
6.4516 & inch ${ }^{2}$ & $\mathrm{~cm}^{2}$ & 0.1550 \\
0.4536 & $\mathrm{lb}$ & $\mathrm{kg}$ & 2.2046 \\
0.0703 & $\mathrm{lb} /$ inch $^{2}$ & $\mathrm{~kg} \cdot \mathrm{cm}^{-2}$ & 14.2233 \\
28.3495 & $\mathrm{oz}$ & $\mathrm{g}$ & 0.0353 \\
$\left({ }^{\circ} \mathrm{F}-32\right) \div 1.8$ & ${ }^{\circ} \mathrm{F}$ & ${ }^{\circ} \mathrm{C}$ & $\left(1.8 \times{ }^{\circ} \mathrm{C}\right)+32$
\end{tabular}


industry produced roughly 59 million pounds of shells per year that could potentially be used as mulch or a container growing substrate. These uses could result in a monetary value of up to \$2.6 million per year. Pecan shells are occasionally used as mulch in landscapes, but most shell waste is left in piles near the shelling facility or is discarded by other methods. If another use for this waste product could be developed, pecan shells might be considered a value-added product of the pecan production waste-product stream. The Oklahoma pecan industry depends primarily on native pecan production, but alternate-bearing tendencies lead to fluctuating annual yields (Wood et al., 2003). A product such as mulch that can be created independently of nut quality may provide an income source. The objective of this research was to evaluate the effect of pecan shells on peach tree productivity and nutrition, weed control, and soil properties.

\section{Materials and methods}

In Feb. 2005, a 'Loring' peach block was established at the Cimarron Valley Research Station in Perkins, $\mathrm{OK}$. There were no known pathogens associated with this site and the site did not previously host a peach planting. This block was planted at a spacing of $18 \times 22 \mathrm{ft}$ on 'Halford' rootstock. 'Loring' was selected for testing pecan shell mulch because it is the most widely grown cultivar in Oklahoma. Trees were headed at planting to about 20 inches and pruned to an open vase system. The soil type was a Teller sandy loam (fine-loamy, mixed, thermic, Udic Argiustoll). The trees were managed according to Oklahoma Cooperative Extension Service recommendations during establishment (McCraw, 2003). Rainfall data (Table 1) were collected throughout the study using the Oklahoma Mesonet (Brock et al., 1995) on site. Irrigation was applied as needed in accordance with recommendations from Taylor and Rieger (2005) and was monitored twice weekly from May through October using Watermark sensors (Irrometer, Riverside, CA) at a depth of 6 inches below the soil surface. The pecan shell mulch originated from York Pecan Company (Foreman, $\mathrm{AR}$ ) and was generally free of residual nut meat. A randomized complete block design with five blocks, four subsamples per block, and five treatments for a total of 20 trees per treatment (Table 2) was used. All plots were sprayed with fluazifop-p-butyl (Fusilade DX; Syngenta Crop Protection, Greensboro, NC) and paraquat (Gramoxone Inteon, Syngenta Crop Protection) before treatment. Glyphosate (RoundUp Original Max; Monsanto, St. Louis) was applied in SPRAY plots after weed ratings at a $2 \%$ solution via backpack sprayer. Treatments were first applied in May 2006. Plot length and width followed the recommendation of Smith et al. (2005) such that a 6-ft-diameter weed-free area was near optimal for pecan tree growth. All flowers and fruit were eliminated by frosts or freezes in 2006 and 2007. Samples for foliar nutrient analysis were taken each year in July from the middle leaf on current season's growth (100 leaves/sample). Leaves were rinsed in tap water, then in $2 \%(\mathrm{v} / \mathrm{v})$ phosphorus $(\mathrm{P})$-free detergent, followed by $0.1 \mathrm{~N}$ hydrochloric acid and deionized (DI) water. Leaves were dried at $70{ }^{\circ} \mathrm{C}$ and ground to pass a 20 -mesh screen. The macro-Kjeldahl method
(Horowitz, 1980) was used for leaf elemental concentrations of $\mathrm{N}$, a colorimetric measure for $\mathrm{P}$ (Olsen and Sommers, 1982), and atomic absorption spectroscopy for other elements. Fertilizer was applied based on foliar analysis from the prior year in Mar. 2007 and Mar. 2008. Soil samples were taken from each block in 2006 and each treatment within a block in 2007 and 2008 at depths of 6 and 12 inches. Soil samples were analyzed at the Oklahoma State University Soil, Water, and Forage Analytical Laboratory (SWFAL) by first oven drying at $60{ }^{\circ} \mathrm{C}$ for $24 \mathrm{~h}$ and ground to pass through a $2-\mathrm{mm}$ sieve. Soil $\mathrm{P}$ was extracted with Mehlich 3 (Mehlich, 1984) and analyzed colorimetrically using a Quickchem 8000 (Mulvaney, 1996 ) automated flow-injection analyzer (LACHAT Instrument, Milwaukee). Soil organic carbon and total $\mathrm{N}$ were determined using a LECO Truspec dry combustion carbon analyzer (LECO, St. Joseph, MI) (Nelson and Sommers, 1996). Plant-available K was extracted using Mehlich 3 extraction solution and analyzed using inductively coupled plasma-atomic

Table 1. Monthly rainfall at the Cimarron Valley Research Station, Perkins, OK, from 2005-08.

\begin{tabular}{lrrrrr}
\hline \multicolumn{5}{c}{ Rainfall $(\mathbf{m m})^{\mathbf{z}}$} \\
\hline Month & $\mathbf{2 0 0 5}$ & $\mathbf{2 0 0 6}$ & $\mathbf{2 0 0 7}$ & $\mathbf{2 0 0 8}$ & 30-year avg \\
\hline January & 87 & 20 & 39 & 16 & 32 \\
February & 47 & 5 & 16 & 61 & 42 \\
March & 15 & 51 & 134 & 97 & 78 \\
April & 14 & 113 & 71 & 118 & 89 \\
May & 71 & 80 & 258 & 159 & 145 \\
June & 136 & 57 & 350 & 130 & 112 \\
July & 54 & 53 & 176 & 114 & 67 \\
August & 225 & 43 & 58 & 39 & 70 \\
September & 84 & 68 & 65 & 42 & 106 \\
October & 51 & 38 & 91 & 54 & 85 \\
November & 0 & 39 & 16 & 124 & 67 \\
December & 2 & 66 & 29 & 28 & 47 \\
Total & 786 & 633 & 1,303 & 982 & 940 \\
\hline
\end{tabular}

${ }^{\mathrm{z}} 1 \mathrm{~mm}=0.0394$ inch.

Table 2. Five treatments used under 'Loring' peach trees at the Cimarron Valley Research Station, Perkins, OK, with accompanying descriptions.

\begin{tabular}{lll}
\hline Name & \multicolumn{1}{c}{ Treatment $^{\mathrm{z}}$} & \multicolumn{1}{c}{ Description $^{\mathrm{z}}$} \\
\hline MOW & Weedy control & $\begin{array}{l}\text { No mulch, no herbicide, mow only } \\
\text { GPRAY }\end{array}$ \\
Herbicide & weed ratings \\
TWO & 2 inches deep & $6 \mathrm{ft}$ long $\times 6 \mathrm{ft}$ wide $\times 2$-inches deep mulch \\
FOUR & 4 inches deep & $6 \mathrm{ft}$ long $\times 6 \mathrm{ft}$ wide $\times 4$-inches deep mulch \\
SIX & 6 inches deep & $6 \mathrm{ft}$ long $\times 6 \mathrm{ft}$ wide $\times 6$-inches deep mulch \\
\hline
\end{tabular}

${ }^{2} 1$ inch $=2.54 \mathrm{~cm}, 1 \mathrm{ft}=0.3048 \mathrm{~m}$. 
emission spectroscopy (ICP-AES; Spectro Ciros, Fitchburg, MA). The soil $\mathrm{pH}$ was measured with a combination glass electrode in soil suspension containing 1:1 soil-to-DI water (Thomas, 1996).

Harvest was performed on a single-tree basis with no flower or fruit thinning during the harvest year (2008). Soluble solid concentrations (SSC) were measured on a random sample of one fruit from each tree from each block. All growth parameter measurements [tree height, trunk cross-sectional area (TCSA), and pruning weights] were measured during the dormant season. Yield efficiency (YE) was calculated as annual yield divided by TCSA. Average fruit weight was calculated as total harvest weight divided by the total number of fruit harvested on each tree. Trunk cross sectional area was measured in the dormant season at 6 inches above the graft union. Tree height was measured from ground level to the tallest shoot. Pruning fresh weights were collected for each tree before budbreak in 2007 and 2008. Weed density was rated in spring (April), summer (July), and fall (November) with herbicide application following rating to the SPRAY treatment. Ratings were based on visual observations on a 1 to 5 scale of approximate weed coverage within the mulched area, where $1=0 \%$ to $19 \%$ weed coverage, $2=20 \%$ to $39 \%, 3=40 \%$ to $59 \%, 4=$ $60 \%$ to $79 \%$, and $5=80 \%$ to $100 \%$.

Analysis of variance was performed in JMP 7.0 (SAS Institute, Cary, NC) with mean separations determined by Tukey-Kramer honestly significant difference (HSD) at $P \leq 0.05$.

\section{Results and discussion}

WeEd DENSITY. Weed density ratings in the MOW treatment were the highest, as would be expected (Table 3). By Apr. 2007, MOW was nearly completely covered with weeds, with SPRAY and TWO somewhat better, and FOUR and SIX nearly devoid of weeds. By July 2007, MOW plots were covered or nearly so. The SPRAY plots were treated after the April rating and thus had a lower rating for July. TWO had greater weed coverage than FOUR or SIX. In Nov. 2007 , TWO increased in weed coverage, as the thinner layer of the mulch application began to settle and break down. By Nov. 2008, TWO provided no better weed control than MOW. Weed density in treatments FOUR and SIX increased by Nov. 2008. This can be attributed to the breakdown of the pecan mulch, indicating a need for reapplication. The discrepancy between the Nov. 2007 and Nov. 2008 SPRAY can be attributed to a missed application after harvest in 2008.

Tree growth. The pecan shell mulch treatments applied in May 2006 were not in place long enough to affect tree growth during the first year (Table 4). Tree height, pruning weights, and TCSA were smallest in the MOW treatment in 2007 , but TCSA and tree height did not differ among SPRAY and the mulch treatments that year (Table 4). Smith et al. (2000) found that tree height and diameter of pecan trees were positively related to mulch area ( 1 or $2 \mathrm{~m}$ squares and $30 \mathrm{~cm}$ deep). They concluded that a 2-mwide wood chip mulch application, $30 \mathrm{~cm}$ deep, in combination with 4$\mathrm{m}$-wide weed-free strip, resulted in the greatest tree growth. Tworkoski and Glenn (2001) reported that grass

Table 3. Weed density ratings by treatment for spring, summer, and fall in 2 years following mulch application under 'Loring' peach trees.

\begin{tabular}{|c|c|c|c|c|c|c|}
\hline \multirow[b]{3}{*}{ Treatment $^{\mathrm{z}}$} & \multicolumn{6}{|c|}{ Weed density ratings $(1-5 \text { scale })^{\mathrm{y}}$} \\
\hline & \multicolumn{3}{|c|}{2007} & \multicolumn{3}{|c|}{2008} \\
\hline & Apr. & July & Nov. & Apr. & July & Nov. \\
\hline MOW & $4.4 \mathrm{a}^{\mathrm{x}}$ & $5.0 \mathrm{a}$ & $5.0 \mathrm{a}$ & $5.0 \mathrm{a}$ & $5.0 \mathrm{a}$ & $5.0 \mathrm{a}$ \\
\hline SPRAY & $3.1 \mathrm{~b}$ & $1.3 \mathrm{c}$ & $1.1 \mathrm{~d}$ & $3.4 \mathrm{~b}$ & $1.8 \mathrm{~cd}$ & $4.1 \mathrm{bc}$ \\
\hline TWO & $2.1 \mathrm{c}$ & $2.7 \mathrm{~b}$ & $3.7 \mathrm{~b}$ & $3.9 \mathrm{~b}$ & $4.4 \mathrm{~b}$ & $4.5 \mathrm{ab}$ \\
\hline FOUR & $1.1 \mathrm{~d}$ & $1.1 \mathrm{c}$ & $1.7 \mathrm{c}$ & $1.7 \mathrm{c}$ & $2.0 \mathrm{c}$ & $3.6 \mathrm{~cd}$ \\
\hline SIX & $1.0 \mathrm{~d}$ & $1.1 \mathrm{c}$ & $1.2 \mathrm{~d}$ & $1.1 \mathrm{~d}$ & $1.4 \mathrm{~d}$ & $3.0 \mathrm{~d}$ \\
\hline
\end{tabular}

${ }^{\mathrm{z}} \mathrm{MOW}=$ mow only, SPRAY $=$ glyphosate herbicide spray, TWO = 2-inch-deep mulch, FOUR $=4$-inch-deep mulch, SIX $=6$-inch-deep mulch; 1 inch $=2.54 \mathrm{~cm}$.

${ }^{y} 1=0 \%$ to $19 \%$ weed coverage, $2=20 \%$ to $39 \%$ weed coverage, $3=40 \%$ to $59 \%$ weed coverage, $4=60 \%$ to $79 \%$ weed coverage, $5=80 \%$ to $100 \%$ weed coverage.

${ }^{x}$ Means within columns followed by the same letter do not significantly differ as determined by Tukey-Kramer honestly significant difference (HSD) at $P \leq 0.05$.

Table 4. Growth parameters measured over 3 years for 'Loring' peaches at the Cimarron Valley Research Station, Perkins, OK.

\begin{tabular}{|c|c|c|c|c|c|c|c|c|}
\hline \multirow[b]{2}{*}{ Treatment $^{\mathrm{z}}$} & \multicolumn{3}{|c|}{$\operatorname{TCSA}\left(\mathrm{cm}^{2}\right)^{y}$} & \multicolumn{3}{|c|}{ Avg tree ht $(m)^{x}$} & \multicolumn{2}{|c|}{$\underset{\left(\mathrm{kg} / \text { tree }^{\mathrm{x}}\right.}{\operatorname{Avg} \text { pruning } w t}$} \\
\hline & 006 & 2007 & 2008 & 2006 & 2007 & 2008 & 2007 & 2008 \\
\hline$N$ & $99^{w}$ & $5.73 \mathrm{~b}$ & 8.6 & 1.28 & 2.0 & 2.8 & 1.05 & 4.10 \\
\hline SPRAY & 1.01 & $7.90 \mathrm{a}$ & $29.92 \mathrm{a}$ & 1.32 & $2.15 \mathrm{a}$ & $3.18 \mathrm{a}$ & $1.71 \mathrm{~b}$ & $7.73 \mathrm{a}$ \\
\hline TWO & 0.95 & $9.21 \mathrm{a}$ & $29.20 \mathrm{a}$ & 1.28 & $2.18 \mathrm{a}$ & $3.03 \mathrm{ab}$ & $2.02 \mathrm{ab}$ & $7.73 \mathrm{a}$ \\
\hline FOUR & 0.86 & $8.94 \mathrm{a}$ & $28.92 \mathrm{a}$ & 1.27 & $2.13 \mathrm{a}$ & $3.06 \mathrm{a}$ & $2.26 \mathrm{a}$ & $7.39 \mathrm{a}$ \\
\hline SIX & 0.96 & $8.84 \mathrm{a}$ & $28.90 \mathrm{a}$ & 1.31 & $2.12 \mathrm{a}$ & $3.05 \mathrm{ab}$ & $2.05 \mathrm{ab}$ & $8.34 \mathrm{a}$ \\
\hline
\end{tabular}

${ }^{\mathrm{z}} \mathrm{MOW}=$ mow only, SPRAY $=$ glyphosate herbicide spray, $\mathrm{TWO}=2$-inch-deep mulch, FOUR $=4$-inch-deep mulch, SIX $=6$-inch-deep mulch; 1 inch $=2.54 \mathrm{~cm}$.

'Trunk cross-sectional area; $1 \mathrm{~cm}^{2}=0.1550$ inch $^{2}$.

${ }^{\mathrm{x}} \mathrm{l} \mathrm{m}=3.2808 \mathrm{ft}, 1 \mathrm{~kg}=2.2046 \mathrm{lb}$

"Means within columns followed by the same letter do not significantly differ as determined by Tukey-Kramer honestly significant difference (HSD) at $P \leq 0.05$. Columns without letters following means were not significantly different. 
Table 5. Soil $\mathrm{pH}$ properties by year and soil depth for all treatments over 2 years under 'Loring' peach trees at the Cimarron Valley Research Station at Perkins, OK.

\begin{tabular}{|c|c|c|c|c|}
\hline \multirow[b]{2}{*}{ Treatment $t^{z}$} & \multicolumn{2}{|c|}{2007} & \multicolumn{2}{|c|}{2008} \\
\hline & $\begin{array}{c}\text { Depth } \\
(6 \text { inches })^{z}\end{array}$ & $\begin{array}{c}\text { Depth } \\
\text { (12 inches) }\end{array}$ & $\begin{array}{c}\text { Depth } \\
\text { (6 inches) }\end{array}$ & $\begin{array}{c}\text { Depth } \\
\text { (12 inches) }\end{array}$ \\
\hline MOW & $6.32^{y}$ & 6.42 & $6.28 \mathrm{a}$ & 6.32 \\
\hline SPRAY & 6.24 & 6.22 & $6.06 \mathrm{ab}$ & 6.14 \\
\hline TWO & 6.04 & 6.32 & $6.00 \mathrm{ab}$ & 6.24 \\
\hline FOUR & 6.06 & 6.26 & $5.88 \mathrm{~b}$ & 6.22 \\
\hline SIX & 6.12 & 6.30 & $5.92 \mathrm{ab}$ & 6.08 \\
\hline
\end{tabular}

${ }^{\mathrm{z}} \mathrm{MOW}=$ mow only, $\mathrm{SPRAY}=$ glyphosate herbicide spray, $\mathrm{TWO}=2$-inch-deep mulch, FOUR $=4$-inch-deep mulch, SIX $=6$-inch-deep mulch; 1 inch $=2.54 \mathrm{~cm}$

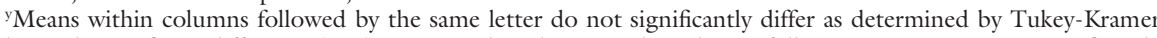
honestly significant difference (HSD) at $P \leq 0.05$. Columns without letters following means were not significantly different.

pecan shell treatments throughout the study. Average pretreatment $\mathrm{pH}$ taken in 2006 at 6 and 12 inches was 6.82 and 6.32 , respectively. Average post-treatment $\mathrm{pH}$ overall treatments decreased in 2007 to 6.16 and 6.30 at 6 and 12 inches, respectively. In $2008, \mathrm{pH}$ declined further to 6.03 and 6.20 at 6 and 12 inches, respectively. The decrease in $\mathrm{pH}$ provided by the pecan shell mulch could improve plant growth and quality of fruit species such as blueberries ( Vaccinium spp.) that require acid soils, while reducing or eliminating the amount of added sulfur $(S)$ needed to reduce $\mathrm{pH}$.

Tree nutrition. Foliar analysis revealed no treatment effect for $\mathrm{S}$, calcium $(\mathrm{Ca})$, nickel $(\mathrm{Ni})$, copper $(\mathrm{Cu})$, manganese $(\mathrm{Mn})$, iron $(\mathrm{Fe})$, and magnesium $(\mathrm{Mg})$ (data not presented), and all were within the sufficiency range (Lockwood et al., 2005). Data for P were only available in 2006 (data were lost for 2007 and 2008) and significant differences occurred between treatments (Table 6), with the SIX treatment providing the most $\mathrm{P}$ and MOW the least. Phosphorous appeared to trend higher as mulch depth increased. Pecan shell mulch treatments increased $\mathrm{N}, \mathrm{K}$, and $\mathrm{Zn}$ content in the foliage during the first year (Table 6). The effect lasted into 2007 for N in the SPRAY treatment, but by 2008 , most treatments were similar to MOW with the exception of FOUR. Foliar K and $\mathrm{Zn}$ content did not differ between pecan shell treatments and MOW or SPRAY in 2007 or 2008 . Foliar $\mathrm{Zn}$ content was highest in the deepest mulch treatments during first year, but did not differ in the following years.

FRUIT YIELD. First harvest yield data showed that the weedy control treatment (MOW) was significantly less than two of the four weedfree treatments (SPRAY and FOUR) with $13.1 \mathrm{~kg} /$ tree and 93 fruit/tree (Table 7 ), a finding that concurs with previous studies (Glenn and Newell, 2008; Tworkoski and Glenn, 2001). Pecan shell mulch treatments and SPRAY did not differ. Yield efficiency, soluble solid concentration, and average fruit weight did not differ among treatment $(P=0.1003,0.3328$, and 0.6688 , respectively) (Table 7 ).
Competition from weeds did not affect fruit quality, but retarded yields and fruit number per tree through competition for moisture and nutrients or potential allelopathic effects as observed in other studies (Glenn and Newell, 2008; Smith et al., 2001; Weller et al., 1985).

Tree mortality. Tree mortality increased with the depth of pecan mulch. SPRAY had no tree loss and MOW and TWO had little tree loss (5\%), whereas FOUR and SIX had an unacceptable mortality rate (15\% and $35 \%$, respectively). Peach has little tolerance for waterlogged soils, with tree death reported in as little as $2 \mathrm{~d}$ of inundation (Kozlowski, 1997). During June and July 2007, trees had a soil moisture status of less than $10 \mathrm{cbar}$ for up to 6 weeks (data not presented), which would limit oxygen availability to the roots (Taylor and Rieger, 2005). Thus, the primary reason for mortality was likely due to record rainfall in 2007 coupled with the longer moisture retention from deeper mulch (Baxter, 1970; Black, 1963).

Pecan shell mulch could provide peach or other fruit producers with another option for weed control; however, mulch that is applied too deep ( 6 inches) or too thin ( 2 inches) may create problems. Mulch that is too deep may cause soil waterlogging in wet years, and thin applications will need to be reapplied every other year to maintain effective weed control. Although untested in this experiment, pecan shells have significant amounts of phenolic compounds (Villarreal-Lozoya et al., 2007) that may also lead to adverse allelopathic effects with long-term use. From this experiment, it appears that the FOUR treatment of pecan shell mulch provided a long-lasting benefit for weed control and had as good or better tree

Table 6. Effect of treatment on nutrient concentration of foliar phosphorus $(\mathrm{P})$, nitrogen $(\mathrm{N})$, potassium $(\mathrm{K})$, and zinc $(\mathrm{Zn})$ collected in July 2006-08 for 'Loring' peach trees.

\begin{tabular}{|c|c|c|c|c|c|c|c|c|c|c|}
\hline \multirow[b]{2}{*}{ Treatment $^{\mathrm{z}}$} & \multicolumn{4}{|c|}{2006} & \multicolumn{3}{|c|}{2007} & \multicolumn{3}{|c|}{2008} \\
\hline & $\mathbf{P}(\%)$ & N (\%) & K (\%) & $\mathrm{Zn}\left(\mathrm{mg} \cdot \mathrm{g}^{-1}\right)^{\mathrm{y}}$ & N (\%) & K (\%) & $\mathrm{Zn}\left(\mathrm{mg} \cdot \mathrm{g}^{-1}\right)$ & $\mathbf{N}(\%)$ & K (\%) & $\mathrm{Zn}\left(\mathrm{mg} \cdot \mathrm{g}^{-1}\right)$ \\
\hline MOW & $0.162 \mathrm{~d}^{\mathrm{x}}$ & $2.77 \mathrm{c}$ & $1.97 \mathrm{c}$ & $12.48 \mathrm{c}$ & $2.55 \mathrm{~b}$ & 2.42 & 16.64 & $2.37 \mathrm{~b}$ & 2.02 & 12.40 \\
\hline TWO & $0.208 \mathrm{bc}$ & $3.63 \mathrm{a}$ & $2.57 \mathrm{ab}$ & $15.25 \mathrm{~b}$ & $2.86 \mathrm{ab}$ & 2.50 & 18.52 & $2.44 \mathrm{ab}$ & 2.06 & 11.98 \\
\hline FOUR & $0.214 \mathrm{ab}$ & $3.58 \mathrm{ab}$ & $2.68 \mathrm{a}$ & $17.82 \mathrm{a}$ & $2.79 \mathrm{ab}$ & 2.58 & 17.00 & $2.59 \mathrm{a}$ & 2.02 & 13.54 \\
\hline SIX & $0.230 \mathrm{a}$ & $3.64 \mathrm{a}$ & $2.70 \mathrm{a}$ & $19.50 \mathrm{a}$ & $2.82 \mathrm{ab}$ & 2.74 & 18.34 & $2.43 \mathrm{ab}$ & 2.14 & 12.78 \\
\hline
\end{tabular}

${ }^{\mathrm{z}} \mathrm{MOW}=$ mow only, SPRAY $=$ glyphosate herbicide spray, TWO $=2$-inch-deep mulch, FOUR = 4-inch-deep mulch, SIX = 6-inch-deep mulch; 1 inch $=2.54 \mathrm{~cm}$.

${ }^{y} 1 \mathrm{mg} \cdot \mathrm{g}^{-1}=0.1 \%$.

${ }^{x}$ Means within columns followed by the same letter do not significantly differ as determined by Tukey-Kramer honestly significant difference (HSD) at $P \leq 0.05$. Columns without letters following means were not significantly different. 
Table 7. 'Loring' peach tree fruit yield, yield efficiency, number of fruit per tree, average fruit weight, and soluble solids concentration (SSC) by treatment in 2008.

\begin{tabular}{lccccc}
\hline Treatment $^{\mathrm{z}}$ & $\begin{array}{c}\text { Avg yield } \\
(\mathbf{k g} / \text { tree })^{\mathbf{y}}\end{array}$ & $\begin{array}{c}\text { Yield efficiency } \\
\left(\mathbf{k g} \cdot \mathbf{c m}^{-2} \text { TCSA }\right)^{\mathrm{x}}\end{array}$ & $\begin{array}{c}\text { Avg fruit } \\
\text { per tree (no. })\end{array}$ & $\begin{array}{c}\text { Avg fruit } \\
\mathbf{w t}(\mathbf{g})^{\mathbf{w}}\end{array}$ & $\begin{array}{c}\text { SSC } \\
(\mathbf{\%})\end{array}$ \\
\hline MOW & $13.1 \mathrm{~b}^{\mathrm{v}}$ & 0.22 & $93 \mathrm{~b}$ & 141 & 12.7 \\
SPRAY & $21.2 \mathrm{a}$ & 0.28 & $165 \mathrm{a}$ & 128 & 11.7 \\
TWO & $20.1 \mathrm{ab}$ & 0.26 & $150 \mathrm{ab}$ & 134 & 12.1 \\
FOUR & $26.4 \mathrm{a}$ & 0.33 & $195 \mathrm{a}$ & 135 & 12.3 \\
SIX & $20.0 \mathrm{ab}$ & 0.26 & $156 \mathrm{ab}$ & 128 & 13.0 \\
\hline
\end{tabular}

${ }^{z} \mathrm{MOW}=$ mow only, SPRAY $=$ glyphosate herbicide spray, TWO $=2$ inches deep mulch, FOUR $=4$ inches deep mulch, SIX $=6$ inches deep mulch; 1 inch $=2.54 \mathrm{~cm}$.

${ }^{\mathrm{y}} 1 \mathrm{~kg}=2.2046 \mathrm{lb}$.

${ }^{x} \mathrm{l} \mathrm{kg} \cdot \mathrm{cm}^{-2}=14.2233 \mathrm{lb} /$ inch $^{2}$, TCSA $=$ trunk cross-sectional area.

${ }^{\mathrm{w}} 1 \mathrm{~g}=0.0353 \mathrm{oz}$

${ }^{\mathrm{v}}$ Means within columns followed by the same letter do not significantly differ as determined by Tukey-Kramer honestly significant difference (HSD) at $P \leq 0.05$. Columns without letters following means were not significantly different.

growth and fruit yield as the herbicide treatment; however, tree mortality was higher than the MOW, SPRAY, and TWO treatments.

\section{Literature cited}

Baxter, P. 1970. Orchard soil management trials: 1. Effect of a weed-free or straw mulched strip on the growth and yield of young fruit trees. Aust. J. Exp. Agr. Anim. Husb. 10:467-473.

Belding, R.D., B.A. Majek, G.R.W. Lokaj, J. Hammerstedt, and A.O. Ayeni. 2004. Orchard floor management influence on summer annual weeds and young peach tree performance. Weed Technol. 18:215-222.

Black, J.D.F. 1963. Development of an impermeable layer under straw mulch in a soil management trial. Aust. J. Exp. Agr. Anim. Husb. 3:101-104.

Black, R.J., E.F. Gillman, G.W. Knox, and K.C. Ruppert. 1994. Mulches for the landscape. Univ. Florida Coop. Ext. Serv. Fact Sheet ENH 103.

Brock, F.V., K.C. Crawford, R.L. Elliott, G.W. Cuperus, S.J. Stadler, H.L. Johnson, and M.D. Eilts. 1995. The Oklahoma Mesonet: A technical overview. J. Atmos. Ocean. Technol. 12:5-19.

Cole, R.J., J.W. Dorner, R.H. Cox, R.A. Hill, H.G. Cluter, and J.M. Wells. 1981. Isolation of Citreoviridin from Penicillium charlesii cultures and molded pecan fragments. Appl. Environ. Microbiol. 42:677-681

Foshee, W.G., III, W.D. Goff, K.M. Tilt, J.D. Williams, J.S. Bannon, and J.B. Witt. 1996. Organic mulches increase growth of young pecan trees. HortScience 31:811-812.

Foshee, W.G., III, W.D. Goff, M.G. Patterson, K.M. Tilt, W.A. Dozier, Jr.,
L.S. Tucker, and J.S. Bannon. 1999. Organic mulches affect soil and leaf nutrient levels of young pecan trees. J. Arboriculture 25:81-84.

Glenn, D.M. and M.J. Newell. 2008. Long-term effects of sod competition on peach yield. HortTechnology 18:445-448.

Horowitz, W. 1980. Official methods of analysis for the Association of Analytical Chemists. 13th ed. Assn. Offic. Anal. Chemists, Washington, DC.

Kozlowski, T.T. 1997. Responses of woody plants to flooding and salinity. Tree Physiology Monograph No. 1.

Lockwood, D.W., M.E. Ferree, and S.C. Myers. 2005. Nutrition, p. 75-84. In: D. Horton and D. Johnson (eds.). Southeastern peach growers' handbook. Georgia Ext. Serv. Hdbk. No. 1.

Lord, W.J. and E. Vlach. 1973. Responses of peach trees to herbicides, mulch, mowing, and cultivation. Weed Sci. 21:227-229.

McCraw, D. 2003. Planting and early care of the peach orchard. Oklahoma Coop. Ext. Fact Sheet HLA-6244.

Mehlich, A. 1984. Mehlich 3 soil extractant: A modification of Mehlich 2 extractant. Commun. Soil Sci. Plant Anal. 15:1409-1416.

Merwin, I.A., D.A. Rosenberger, C.A. Engle, D.L. Rist, and M. Fargione. 1995. Comparing mulches, herbicides, and cultivation as orchard groundcover management systems. HortTechnology 5:151-158.

Mexal, J.G., E.A. Herrera, T.W. Sammis, and W.H. Zachritz. 2003. Noncommensurable values of the pecan industry. New Mexico State Univ. Coop. Ext. Serv. Guide H-654.

Mulvaney, R.L. 1996. Nitrogen: Inorganic forms, p. 1123-1184. In: D.L.
Sparks, A.L. Page, P.A. Helmke, R.H. Loeppert, P.N. Soltanpour, M.A. Tabataba, C.T. Johnston and M.E. Sumner (eds.). Methods of soil analysis. Part 3, Chemical methods. Book Ser. 5. Soil Sci. Soc. Amer., Madison, WI.

Nelson, D.W. and L.E. Sommers. 1996. Total carbon, organic carbon, and organic matter, p. 961-1010. In: D.L. Sparks, A.L. Page, P.A. Helmke, R.H. Loeppert, P.N. Soltanpour, M.A. Tabataba, C.T. Johnston and M.E. Sumner (eds.). Methods of soil analysis. Part 3, Chemical methods. Book Ser. 5. Soil Sci. Soc. Amer., Madison, WI.

Olsen, S.R. and L.E. Sommers. 1982. Phosphorous, p. 404-430. In: A.L. Page, R.H. Miller, and D.R. Keeney (eds.). Methods of soil analysis. Part 2, Chemical and microbiological properties. Amer. Soc. Agron., Madison, WI.

Parker, M.L. and J.R. Meyer. 1996. Peach tree vegetative and root growth respond to orchard floor management. HortScience 31:330-333.

Porter, G., R. Yost, and M. Nagao. 2005. The application of macadamia nut husk and shell mulch to mature Macadamia integrifolia to improve yields, increase nutrient utilization, and reduce soil $\mathrm{P}$ levels. Western Nutrient Mgt. Conf. 6: 226-233.

Skelly, S.M. 2005. Mulches for the landscape. Mississippi State Univ. Ext. Serv. Publ. 2301.

Smith, M.W. 2000. Cultivar and mulch affect cold injury of young pecan trees. J. Amer. Pomol. Soc. 54:29-33.

Smith, M.W., B.L. Carroll, and B.S. Cheary. 2000. Mulch improves pecan tree growth during orchard establishment. HortScience 35:192-195.

Smith, M.W., B.S. Cheary, and B.L. Carroll. 2005. Size of vegetation free area affects nonbearing pecan tree growth. HortScience 40:1298-1299.

Smith, M.W., M.E. Wolf, B.S. Cheary, and B.L. Carroll. 2001. Allelopathy of bermudagrass, tall fescue, redroot pigweed, and cutleaf evening primrose on pecan. HortScience 36:1047-1048.

Stefanelli, D., R.J. Zoppolo, R.L. Perry, and F. Weibel. 2009. Organic orchard floor management systems for apple effect on rootstock performance in the midwestern United States. HortScience 44:263267.

Taylor, K.C. and M. Rieger. 2005. Irrigation scheduling, p. 100-105. In: D. Horton and D. Johnson (eds.). Southeastern peach growers' handbook. Georgia Ext. Serv. Hdbk. No. 1. 


\section{Research Reports}

Thomas, G.W. 1996. Soil pH and soil acidity, p. 475-490. In: D.L. Sparks, A.L. Page, P.A. Helmke, R.H. Loeppert, P.N. Soltanpour, M.A. Tabataba, C.T. Johnston and M.E. Sumner (eds.). Methods of soil analysis. Part 3, Chemical methods. Book Ser. 5. Soil Sci. Soc. Amer., Madison, WI.

Tworkoski, T.J. and D.M. Glenn. 2001. Yield, shoot and root growth, and phys- iological responses of mature peach trees to grass competition. HortScience 36 1214-1218.

Villarreal-Lozoya, J.E., L. Lombardini, and L. Cisneros-Zevallos. 2007. Phytochemical constituents and antioxidant capacity of different pecan [Carya illinoinensis (Wangenh.) K. Koch] cultivars. Food Chem. 102:1241-1249.
Weller, S.C., W.A. Skroch, and T.J. Monaco. 1985. Common bermudagrass (Cyndon dactylon) interference in newly planted peach (Prunus persica) trees. Weed Sci. $33: 50-56$.

Wood, B.W., P. Conner, and R. Worley. 2003. Relationship of alternate bearing intensity in pecan to fruit and canopy characteristics. HortScience 38:361-366. 